\title{
SHIFTING REPERTOIRES: MIGRATION AND CHINESE LANGUAGES IN FRANCE
}

\begin{abstract}
Summary. This paper shows that the language repertoires of Chinese migrants to Paris, France, have been shifting in the last 15 years, due to both sociological and sociolinguistic changes that occurred since the early 2000s. On the sociological side, although migration from China to France is still ongoing, it co-occurs with the formation of a generation of ethnic Chinese children and youths born in France from migrant parents. On the sociolinguistic side, it has been shown that the equilibrium between the standard Chinese national language (Putonghua) and the local Chinese languages (fangyan or "dialects") was no longer that of a diglossic situation where the standard language would be excluded from the family and friends' domain of interaction. The consequences of both changes were explored through a small-scale questionnaire survey addressed to ethnic Chinese children and youths in Paris. These recent data were compared with similar data gathered in 2000, thus pointing to a real shift in language repertoires among Chinese migrants to France. The study ends by considering some implications of our findings for heritage language teaching.
\end{abstract}

Keywords: language repertoire, language use, language attitudes, Chinese, migration, questionnaire survey.

\section{Introduction}

The Chinese language has gained considerable visibility as a global language over recent years in France. While this can be analyzed as the consequence of several distinct factors (sharp rise in the number of Chinese migrants since the $1980 \mathrm{~s}^{3}$, steadily growing demand for Chinese courses in the French primary and secondary teaching system since the early $2000 \mathrm{~s}^{4}$ ), it should be emphasized that what is perceived as "the Chinese language" is in fact more complex. Although there is a standard Chinese language, called Putonghua in China and "Mandarin Chinese" abroad, China is home to a multiplicity of Chinese languages or dialects $^{5}$. As a consequence, Chinese migrants established in France speak different Chinese "dialects", sometimes in addition to the standard language. However, the sociolinguistic situation in China, that could be described as

\footnotetext{
${ }^{3}$ For details, see Cattelain et al. (2002, pp. 33-38; 2005, pp. 27-28).

4 Based on the sheer number of learners in French secondary schools (33,455 in 2015, as compared to approximately 15,000 in 2006), Chinese comes as the fifth foreign language taught, after English, Spanish, German, and Italian. (French Ministry of Education 2015, pp. 123).

${ }^{5}$ The Chinese themselves use the term fangyan (often referred to as "dialects" in English) for local languages with various sociolinguistic statuses, that belong to nine Chinese language families. Mair (1991) discusses the signification of terms such as "dialects" or "topolects" (a closer translation of fangyan) in China.
} 
diglossic (Ferguson 1959) in the second half of the 20th century - with Mandarin Chinese endowed with all the attributes of a High variety, and Chinese dialects keeping their ground as steadily transmitted Low varieties - has been shown to be evolving quickly in the 2000s, so that standard Chinese is gaining ground in domains that were hitherto the realm of local languages (Saillard, 2004).

Thus, a study by Boutet and Saillard conducted in 2000 showed that Chinese migrant children in Paris indeed inherited the diglossic linguistic system pervasive in China, while readjusting to a new linguistic environment where the French language competed with the two varieties of Chinese languages both in the domain of official uses (in school and in the society at large) and that of private uses (in the friendly and domestic domains) (Saillard \& Boutet 2001, Boutet \& Saillard 2003, 2013). Knowing that Mandarin Chinese (Putonghua) was involved in a "vernacularization" process in Mainland China, our interest for the present article has been to enquire whether this new equilibrium transferred to the language uses and representations of present-day Chinese migrants in France. Based on the comparison between former publications and the results of a 2010 questionnaire survey, this article tries to show that there has been a shift in language uses and attitudes towards languages among migrant children and youths from Chinese origins in Paris.

In the following, we will retrace briefly the history of Chinese migration to France since the early XXth century. We will then recall the main findings of the 2000 survey conducted by Boutet and Saillard, in order to appreciate the changes revealed by the later survey described in the third part of the article. Last, we will discuss the results of this comparison and point to a few remaining questions.

\section{Highlights on Chinese migration to France}

Chinese migration to Europe can be said to have begun in the Twentieth century, becoming more intense in its last quarter. Trolliet (1994, pp. 35), quoting a 1989 Chinese source, states that Chinese migrants were then distributed through Europe as follows: first the UK and France, with respectively 230,000 and 210,000 Chinese migrants (totaling two thirds of the total number of Chinese migrants settled in Europe), then the Netherlands $(60,000)$, Germany $(20,000)$, and last, Sweden $(5,000)$. Since then, incoming fluxes from China have been 
steadily increasing, and migrants have also settled in Italy, Spain, Portugal and a few Eastern Europe countries, such as Hungary.

Most scholars agree on the fact that Chinese migration to France took place in four distinct "waves" (Ma Mung 2009). The first wave, during the 1920s, was made up of soldiers from Indochina who came to fight in the First World War; some of the survivors stayed in Paris after 1918. Among these Indochinese migrants, many were actually ethnic Chinese from the diaspora. The second wave of Chinese migration to France took place after the Geneva Accords in 1954. Among the Vietnamese people exiled to France, many were ethnic Chinese. Most of them were well-educated or wealthy people. The third wave consisted of "boat people" and began after the end of the Vietnam War, in 1975. Among the refugees were ethnic Chinese from Vietnam and Cambodia. The fourth wave was the first ever to depart from Mainland China. It was triggered by the reforms that took place in China after 1979. As highlighted by Pina-Guerassimof's (2006) study, this fourth migratory wave is much more socially diverse than the preceding three, be it in terms of geographical origin or in terms of education and profession. Furthermore, these migrants are constantly in touch with their place of origin, and have built transnational networks and social practices.

Since the publication in 2002 of the 1999 national census data, there are some data available in France regarding language maintenance and transmission. Four categories of languages were considered in the national census based on a sample of 380,000 adults: the national language, regional languages, migration languages and foreign languages.

Census data show that Chinese languages, as well as Turkish, are among the languages that maintain the best: only $28 \%$ of ethnic Chinese declare they do not speak the language that their own parents spoke to them in their childhood on a regular basis. For comparison's sake, we can cite a regional language such as franco-provençal (90\%), or another migration language such as Arabic (55\%). Nevertheless, it is necessary to be a little more specific when describing the maintenance of the Chinese languages: what is the share of standard Chinese (or Putonghua), as opposed to other Chinese languages? 


\section{Findings of the 2000 survey}

\section{The 2000 interviews}

In 2000, Saillard and Boutet conducted a survey on language use and representations among Chinese children and youths in Paris. ${ }^{6}$ At the time, casual observations of the so-called Chinese Community in France gave the impression that standard Chinese was not the primary Chinese language used by Chinese migrants in France. Standard Chinese was strongly associated with schooling and culture, and seldom acquired in France.

The interviews made by Saillard and Boutet in 2000 were directed towards children and youths from Wenzhou currently living in Paris. Among them, those that had had long schooling in China (at least 9 years of mandatory schooling) before coming to France had a good mastery of spoken and written standard Chinese. Those who had not gone to school in China, and those who had not finished their 9 years, considered themselves still as learners of standard Chinese. For historical reasons, their parents had had less access to education than themselves, so that the children's standard Chinese skills were seldom reinforced by communication with their elders. Given such a context, it was a surprise to us that standard Chinese was still viewed as a big asset for some of these youths and their parents. They would then try to further their Putonghua skills by reading, writing letters, watching Chinese DVDs and Chinese satellite television. They described standard Chinese not only as a language associated with culture, but also as a professional asset.

Nevertheless, this was not the dominant case among the respondents. We found that only a small portion of young Wenzhou migrants kept studying standard Chinese in Paris. Two reasons were often given. The first, given by those who had received part of their education in China, was that although basic, the standard Chinese skills attained were considered sufficient for current purposes. For those who were never schooled in China however, the reason not to study Putonghua was that the child wanted to build her future in France, and her motivation for learning standard Chinese was weak. ${ }^{7}$

\footnotetext{
${ }^{6}$ Saillard and Boutet (2001).

7 Ibid., 34.
} 


\section{Tendencies since 2000}

The tendencies we just described fit well with an analysis of the situation in diglossic terms; in this kind of analysis, standard Chinese would be a High variety and Chinese dialects a Low variety. But, as was shown in Saillard's earlier study, standard Chinese is not confined to such a narrow role in today's Chinese society. ${ }^{8}$ As is the case in China, Chinese migrants to Europe tend to use more and more standard Chinese in their daily lives. Young Wenzhou parents are heard speaking Putonghua to their toddlers; more and more standard Chinese-speaking Dongbei migrant women work as nannies in Wenzhou homes in Paris, some standard Chinese-speaking daycare centers have opened near the districts where Wenzhou migrants live. ${ }^{9}$ When we asked the children which languages they would like to transmit to their own children, standard Chinese was often cited.

In 2010, ten years after Saillard \& Boutet's study, it seemed possible to find out whether the tendencies observed at the time resulted in different language uses among Chinese youths in Paris. A new survey was then launched for this purpose.

\section{Standard Chinese and Chinese migrants in France today: The 2010 survey}

\section{Methodology}

The survey was a questionnaire survey, devised during a 2010 Spring class in Sociolinguistics (third year undergraduates) in Université Paris Diderot. The questionnaires (see Appendix 1 for the English translation of the questionnaire) were written in French and Chinese. They were addressed by 7 French- and Chinese-speaking undergraduates ${ }^{10}$ to 95 (ethnic) Chinese children and youths, during the month of April, 2010. Unfortunately, only 88 questionnaires were found valid for analysis. The respondents were selected

\footnotetext{
${ }^{8}$ Saillard (2004, pp. 163-176).

${ }^{9}$ Cattelain et al. (2005, pp. 43).

10 They were Chen Xiaoye, Fan Weiwei, Hélène Luong, Peng Zhe, Xiao Yin, Zhang Lele and Zhao Chen.
} 
on a voluntary basis among students attending informal private schools (set up in cultural centers, associations, churches in several districts of Paris ${ }^{11}$ ) where they sought to improve either their standard Chinese or French language skills. Each respondent signed a discharge, agreeing to the fact that their responses would be used for research purposes only and that anonymity would be guaranteed.

\section{Participants}

Because of the small number of available respondents, they were not filtered according to age. Based on the 88 valid questionnaires, age of respondents ranged from 7 to 19 years old; their mean age was 12.66 years, and their median age was 13 (see Appendix 2 for detailed age of participants). As for sex of the respondents, we omitted to ask any specific question, which avowedly is a shortcoming of this survey. Only part of the respondents gave their first names, and only part of these names were marked for gender. The overall impression was that female respondents were slightly overrepresented as compared to males.

Thus, because of the small number of respondents and the lack of homogeneity in terms of age or gender representation, we cannot claim that our respondents are representative of all youths and children of Chinese descent in Paris; they are however fairly representative of youths and children of Chinese descent attending language courses organized by Chinese migrant associations in Paris.

\section{Ethical considerations}

In accordance with the French law, which does not allow the publication of "ethnic" statistics, we avoided to ask the respondents any question as to their citizenship (French, Chinese or other) or that of their parents. We assumed they

11 These were: Association Franco-Chinoise Pierre Ducerf; Centre Culture, Langue et Communication; Notre-Dame de Chine; Association d'Assistance Scolaire, Linguistique et Culturelle. 
could be considered "Chinese" children and youths because of their linguistic background: either Putonghua or a Chinese language/dialect (often both) was spoken in their homes. Nevertheless, because part of our hypotheses depended on whether they were born and educated in China or in France, we asked the respondents for their place of birth (Question 2, see Appendix 1) and, when born in China, the length of their stay in France (Question 4), which could be compared to their age (Question 1).

Among the 88 valid questionnaires, half of the respondents (44) were born in China, and half were born either in France (42) or in Italy (2) ${ }^{12}$.

\section{Comparabilty with the 2000 survey}

The children and youths who answered our questionnaire were somewhat different from the Chinese migrant children Saillard and Boutet interviewed in 2000. First of all, we had to take into account the fact that more and more children from Chinese descent were born in France, so that we included such children in the 2010 survey (there were none in the 2000 survey, although some of the respondents did have younger siblings born in France). Second, we did not restrict the respondents to migrants from Wenzhou, contrary to what was the case with the 2000 survey. Among our respondents, some gave Zhejiang as their place of birth (Wenzhou is located in the Zhejiang province, but these respondents could as well be from the neighboring Qingtian, as witnessed by the names of the dialects they provided), other gave Fujian or Fuqing (a city in Fujian Province) as an answer. As for those born in France and Italy (44 people), we did not ask for their parents' place of origin, but some of them named their family dialects (Wenzhouhua, Shandonghua, Cantonese and Chaozhouhua). Whereas the first two "dialects" indicate that their speakers originated from Mainland China, the last two could either indicate that the families came directly from China in recent years, or that they came from Indochina through the second or third wave of migration (see supra).

\footnotetext{
12 One of them went back to China to attend primary school, and then moved to France. In the following, we do not differentiate those two respondents from the ones who were born in France.
} 


\section{Motivations for the questions}

The questions asked (see questionnaire in Appendix 1) were based on four main findings from the 2000 survey that we suspected were no longer valid. The first finding was the link between education in China and mastery of Putonghua. In 2000, the children who were not born and raised in China had very poor Putonghua language skills. The second finding was the role played by the (Wenzhou) dialect in family-internal communication, to the exclusion of Putonghua. The third finding was that reading and writing skills in standard Chinese were considered a key to (Chinese) culture, and that most popular culture was mediated through Chinese (standard or Cantonese), which is to say the Chinese youths we interviewed in 2000 stayed into a restricted Chinesespeaking cultural circle. The last finding was related to language attitudes: the children interviewed in 2000 all wished to transmit the Wenzhou dialect to the next generation (or believed it would be transmitted "naturally"), while only some of them thought transmitting Putonghua was worthwhile.

In the following, we grouped the description of the survey results according to the same four themes.

\section{Modalities of Acquisition}

Based on the 2000 survey, we expected that youths and children born in China had a Chinese dialect as their first language when applicable. As a matter of fact, in the 2000 survey, all respondents came from a dialect-speaking area (the Wenzhou area), so that standard Chinese was never cited as a first language. In the 2010 survey, however, we could not exclude the possibility that part of the respondents were born in standard Chinese-speaking areas. As a consequence, for respondents born in China, we added a question about the city where they were born. The results showed that all respondents born in China were born in "dialectal areas".

The 2000 survey led us to expect that youths and children who were proficient in Putonghua learned the language mainly through schooling in China; as a consequence, those born in France (they represented 44/88 of the 2010 
survey respondents) were not expected to master Putonghua, because they lacked schooling experience in China.

The results of the 2010 survey proved to be different from our expectations. Let us look at the first series of questions (Questions 5 and 6 ) for respondents born in China as compared to those born in France.

\section{First language as related to place of birth}

As shown by Table 1 below, answers differed somewhat depending on whether respondents were born in China or in France.

Table 1.

Mother tongue of respondents as related to place of birth

\begin{tabular}{|c|c|c|c|c|c|c|c|}
\hline & PTH* & PTH+dialect & dialect & French & French+dialect & French+PTH & Total \\
\hline $\begin{array}{c}\text { Born in } \\
\text { China }\end{array}$ & 30 & 5 & 1 & 8 & - & - & 44 \\
\hline $\begin{array}{c}\text { Born in } \\
\text { France }\end{array}$ & 4 & - & 3 & 21 & 9 & 7 & 44 \\
\hline Total & 34 & - & 4 & 29 & 9 & 7 & 88 \\
\hline
\end{tabular}

*PTH $=$ Putonghua

When answering Question 5 ("What is your mother tongue?"), most of the 44 children and youths who were born in China cited only one language (Putonghua, French or a Chinese dialect), and only five of them cited two: Putonghua and a Chinese dialect. Putonghua was the language most often cited, alone (30/44 answers) or in combination with a Chinese dialect. This result is quite surprising, given that dialects are reported to still have strong vitality in non-Mandarin areas, and could be expected to be their first acquired language.

As for respondents born in France, apart from single language answers (either French, or Putonghua, or a Chinese dialect), they cited two different combinations: French plus Putonghua, or French plus a Chinese dialect. The answers including the French language as a mother tongue were clearly dominant (37/44). 


\section{Acquisition Modalities for Standard Chinese}

Question 6 ("Do you speak other languages?"), added to question 5, allowed us to consider all the speakers of Putonghua (L1 or other) among our respondents. There were 69 of them, including all 44 respondents who were born in China. In order to get a little more information on their linguistic background, we asked them if they had had schooling in China (Question 3). A significant part of the respondents who declared they mastered Putonghua (22/69) had had no schooling in China whatsoever. Among the 47 respondents who did attend school in China, 1 reported schooling at the kindergarten level, 26 attended primary school, 10 went through junior high school, and 10 achieved senior high school.

When isolating respondents who were born in France, it appeared that more than half (25/44) declared they mastered Putonghua. However, the remaining 19 children and youths were all studying Putonghua in Paris at the time of the survey.

The question was then to determine how the 25 French-born respondents that claimed to be proficient in Putonghua had acquired the language. The answer to this question (Question 7-a) is illustrated in Table 2 below:

Table 2.

Modes of acquisition of standard Chinese for respondents born in France

\begin{tabular}{|c|c|c|c|c|}
\hline Family & $\begin{array}{c}\text { Language courses } \\
\text { in France }\end{array}$ & $\begin{array}{c}\text { Schooling in } \\
\text { China }\end{array}$ & No answer & Total \\
\hline 11 & 10 & 2 & 2 & 25 \\
\hline
\end{tabular}

Almost half (11/25) youths and children cited family-internal communication as their means of acquiring Putonghua, which could be related to the high number among them citing Putonghua as (one of) their L1. Only ten declared they attended Chinese language courses in non-governmental schools in France, but we could add to this number the 19 respondents who did not claim to be proficient in Putonghua, although they were studying the language in nongovernmental schools in France at that time. Interestingly enough, some of the children who were born in France did have some schooling experience in China. 
The first part of our questionnaire survey thus shows a great difference between the Wenzhou youths that we interviewed in Paris in 2000 and the (ethnic) Chinese youths interviewed in Paris in 2010. The latter tend to master Putonghua, even though many of them (more than half) had no schooling whatsoever in China. Non-governmental Chinese language instruction in France seems to be a major medium for the acquisition of Putonghua, as well as interaction with family members for quite a few respondents. This leads us to the following questions: is Putonghua still considered as a language needed only for interaction outside the family and friends network? More generally, how is Putonghua used in daily life in Paris?

\section{Family and peer-to-peer relations}

The second group of questions (Questions 8-10) was aimed at determining whether Chinese dialects were still the only languages to be used inside families, Putonghua being considered a language to be used in more formal situations, or situations involving (Chinese-speaking) strangers, and French being used for still more remote relationships, typically with non-Chinese strangers. We thus asked the children and youths what languages they used when talking to their parents (Question 8-b), their siblings (Question 8-c for elder siblings and 8-d for younger siblings), and which languages their parents spoke to them (Question 8-a). Results are shown in Table 3 below.

Table 3.

Languages used for interaction in the family domain

\begin{tabular}{|c|c|c|c|c|c|c|c|c|}
\hline & & $\begin{array}{c}\text { Dialect } \\
\text { only }\end{array}$ & $\begin{array}{l}\text { PTH } \\
\text { only }\end{array}$ & $\begin{array}{c}\text { French } \\
\text { only }\end{array}$ & $\begin{array}{c}\text { Dialect } \\
+ \text { PTH }\end{array}$ & $\begin{array}{l}\text { Dialect } \\
\text { +French }\end{array}$ & $\begin{array}{l}\text { PTH+ } \\
\text { French }\end{array}$ & $\begin{array}{c}\text { Dialect+ } \\
\text { French+ } \\
\text { PTH }\end{array}$ \\
\hline \multirow{3}{*}{$\begin{array}{c}\text { Parents } \\
\text { to } \\
\text { youths }\end{array}$} & Total & 27 & 13 & 2 & 30 & 9 & 2 & 6 \\
\hline & $\begin{array}{c}\text { Born in } \\
\text { China }\end{array}$ & 17 & 5 & - & 19 & - & - & 4 \\
\hline & $\begin{array}{l}\text { Born in } \\
\text { France }\end{array}$ & 10 & 8 & 2 & 11 & 9 & 2 & 2 \\
\hline \multirow{3}{*}{$\begin{array}{l}\text { Youths } \\
\text { to } \\
\text { parents }\end{array}$} & Total & 23 & 13 & 3 & 27 & 9 & 2 & 8 \\
\hline & $\begin{array}{c}\text { Born in } \\
\text { China }\end{array}$ & 14 & 5 & 1 & 16 & - & - & 6 \\
\hline & $\begin{array}{l}\text { Born in } \\
\text { France }\end{array}$ & 9 & 8 & 2 & 11 & 9 & 2 & 2 \\
\hline
\end{tabular}


SHIFTING REPERTOIRES: MIGRATION AND CHINESE LANGUAGES IN FRANCE

\begin{tabular}{|c|c|c|c|c|c|c|c|c|}
\hline & & $\begin{array}{c}\text { Dialect } \\
\text { only }\end{array}$ & $\begin{array}{l}\text { PTH } \\
\text { only }\end{array}$ & $\begin{array}{c}\text { French } \\
\text { only }\end{array}$ & $\begin{array}{l}\text { Dialect } \\
+ \text { PTH }\end{array}$ & $\begin{array}{l}\text { Dialect } \\
+ \text { French }\end{array}$ & $\begin{array}{l}\text { PTH+ } \\
\text { French }\end{array}$ & $\begin{array}{c}\text { Dialect+ } \\
\text { French+ } \\
\text { PTH }\end{array}$ \\
\hline \multirow{3}{*}{$\begin{array}{l}\text { Youths } \\
\text { to elder } \\
\text { siblings }\end{array}$} & Total & 12 & 12 & 20 & 9 & 5 & 4 & 3 \\
\hline & $\begin{array}{c}\text { Born in } \\
\text { China }\end{array}$ & 9 & 7 & - & 8 & 2 & 2 & 2 \\
\hline & $\begin{array}{l}\text { Born in } \\
\text { France }\end{array}$ & 3 & 5 & 20 & 1 & 3 & 2 & 1 \\
\hline \multirow{3}{*}{$\begin{array}{c}\text { Youths } \\
\text { to } \\
\text { younger } \\
\text { siblings }\end{array}$} & Total & 11 & 19 & 22 & 7 & 3 & 8 & 4 \\
\hline & $\begin{array}{c}\text { Born in } \\
\text { China }\end{array}$ & 8 & 14 & 2 & 6 & - & 4 & 2 \\
\hline & $\begin{array}{l}\text { Born in } \\
\text { France }\end{array}$ & 3 & 5 & 20 & 1 & 3 & 4 & 2 \\
\hline
\end{tabular}

Just as we expected even for youths and children born in France given the 2000 facts, most parents were reported to use a Chinese dialect to address their children. But contrary to what was found in 2000, a majority of parents also used Putonghua together with the dialect, and some used French in combination with the dialect. Combinations of languages excluding the dialect were scarcer. What seems new compared to 10 years before is the reported use of Putonghua at home, even if in the majority of cases, it is used jointly with the dialect.

For youths born in China, the most reported languages as used by parents are also the Chinese dialect and Putonghua (or a combination of both). French was cited only in combination with the other two.

Thus, the difference between children and youths born in France and those born in China lies primarily in the use of French by parents when addressing them. Moreover, more frequent use of French in parent-to-child communication results in lesser use of the Chinese dialects. Which is to say that the Chinese dialects are more used in the families of children and youths who were born in China.

Languages reported by the respondents in answer to the question "What languages do you speak to your parents?" matched the preceding question ("What languages do your parents speak to you?") quite closely in many respects. Chinese dialect and the combination of Chinese dialect and standard Chinese were still the most reported languages, although they were slightly less dominant. Putonghua only was quite stable as an answer. There is a very slight asymmetry between parents and children regarding the use of French, which can easily be explained in terms of competence. But more important is the fact that, comparing 
to the 2000 survey, the French language has become one of the family languages among Chinese migrants, albeit the less used between parents and children.

Comparing the two answers (parents-to-children and children-toparents), one also notices that children report using slightly less dialect than their elders.

We turn next to the language spoken by children to their siblings. Although we devised two distinct questions for elder and younger siblings, the difference between the two does not seem to be very significant as a whole ${ }^{13}$. Most respondents did not have both elder and younger siblings, or spoke the same language(s) to them. As compared to the languages used between parents and children, the use of French only between siblings is very striking. But it is clear that the "French only" response comes almost exclusively from the children and youths who were born in France. No other language comes close to French in this respect, not even Putonghua, the second most reported language. Thus, French seems to have become the privileged language for same-generation family-internal communication, for those children who were born in France. For those born in China however, dialect and/or Putonghua are used in the majority of cases, French being rarely used alone. For respondents born in China, the use of French is restricted almost only to communication with siblings (only one respondent claims speaking only French to her parents).

Question 9 ("What languages do you speak with Chinese schoolmates?", further divided into 9-a: "from the same area" and 9-b "from other areas in China") was devised to assess whether the determining factor for language choice was age class rather than family relationships. As shown by the answers to question 9 displayed in Table 4 below, there is again a difference according to where the respondents were born. While respondents born in France prefer to use French only for peer-to-peer communication, respondents born in China use Putonghua a great deal, sometimes in combination with French. Dialect is rarely reported as being the sole means of communication with Chinese classmates ${ }^{14}$, but it may enter in combination either with Putonghua or French.

\footnotetext{
${ }^{13}$ In particular, it is not clear at all that more French would be used with younger siblings (liable to have been born in France), and more dialect or Putonghua with elder ones (liable to have been born in China).

${ }^{14}$ Answers citing a Chinese dialect as used with Chinese classmates from a different dialect background seem erratic.
} 
SHIFTING REPERTOIRES: MIGRATION AND CHINESE LANGUAGES IN FRANCE

For both groups, the use of French is reported as either dominant (respondents born in France) or important (combinations including French are no less than combinations excluding it).

Table 4.

Languages used for interaction with Chinese schoolmates

\begin{tabular}{|c|c|c|c|c|c|c|c|c|}
\hline & & $\begin{array}{c}\text { Dialect } \\
\text { only }\end{array}$ & $\begin{array}{l}\text { PTH } \\
\text { only }\end{array}$ & $\begin{array}{c}\text { French } \\
\text { only }\end{array}$ & $\begin{array}{c}\text { Dialect+ } \\
\text { PTH }\end{array}$ & $\begin{array}{c}\text { Dialect+ } \\
\text { French }\end{array}$ & $\begin{array}{l}\text { PTH+ } \\
\text { French }\end{array}$ & $\begin{array}{c}\text { Dialect+ } \\
\text { French+ } \\
\text { PTH }\end{array}$ \\
\hline \multirow{3}{*}{ 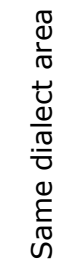 } & Total & 5 & 14 & 41 & 7 & 3 & 14 & 5 \\
\hline & $\begin{array}{c}\text { Born in } \\
\text { China }\end{array}$ & 5 & 12 & 6 & 6 & 1 & 11 & 5 \\
\hline & $\begin{array}{l}\text { Born in } \\
\text { France }\end{array}$ & - & 2 & 35 & 1 & 2 & 3 & - \\
\hline \multirow{3}{*}{ 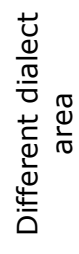 } & Total & 6 & 20 & 40 & 6 & 1 & 6 & 3 \\
\hline & $\begin{array}{c}\text { Born in } \\
\text { China }\end{array}$ & 4 & 13 & 8 & 4 & 1 & 5 & 3 \\
\hline & $\begin{array}{l}\text { Born in } \\
\text { France }\end{array}$ & 2 & 7 & 32 & 2 & - & 1 & - \\
\hline
\end{tabular}

With Questions 11 ("What is the language of your voicemail message?") and 15 ("Which language do you speak when you are among Chinese friends in a public place (on the street, in the metro, in the schoolyard, on a sports field...)?"), we tried to determine whether the respondents preferred using a marked groupinternal language, such as the Chinese dialect, or if they preferred using a "neutral" language such as French. Once again, there is an obvious difference between youths and children born in France and those born in China. As can be seen from the results displayed in Table 5 below, when born in France, the great majority of respondents reported French as the only language used. On the opposite, respondents born in China do not hesitate to display their use of Putonghua in the public arena, although some respondents also claim to use only French, or a combination of both. What is common to both groups is their very scarce use of the heritage dialects in the public sphere. 
Table 5.

Languages used in the public sphere

\begin{tabular}{|c|c|c|c|c|c|c|c|c|}
\hline & & $\begin{array}{c}\text { Dialect } \\
\text { only }\end{array}$ & $\begin{array}{l}\text { PTH } \\
\text { only }\end{array}$ & $\begin{array}{c}\text { French } \\
\text { only }\end{array}$ & $\begin{array}{c}\text { Dialect } \\
+ \text { PTH }\end{array}$ & $\begin{array}{c}\text { Dialect+ } \\
\text { French }\end{array}$ & $\begin{array}{l}\text { PTH+ } \\
\text { French }\end{array}$ & $\begin{array}{c}\text { Dialect+ } \\
\text { French+ } \\
\text { PTH }\end{array}$ \\
\hline \multirow{3}{*}{ 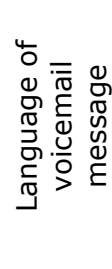 } & Total & 2 & 18 & 43 & 4 & 1 & 5 & 1 \\
\hline & $\begin{array}{l}\text { Born in } \\
\text { China }\end{array}$ & 2 & 17 & 9 & 4 & 1 & 5 & - \\
\hline & $\begin{array}{l}\text { Born in } \\
\text { France }\end{array}$ & - & 1 & 34 & - & - & - & 1 \\
\hline \multirow{3}{*}{ 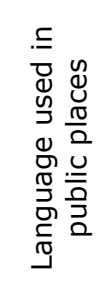 } & Total & 1 & 19 & 36 & 7 & 6 & 13 & 4 \\
\hline & $\begin{array}{c}\text { Born in } \\
\text { China }\end{array}$ & 1 & 18 & 5 & 6 & - & 8 & 3 \\
\hline & $\begin{array}{l}\text { Born in } \\
\text { France }\end{array}$ & - & 1 & 31 & 1 & 6 & 5 & 1 \\
\hline
\end{tabular}

The cultural functions of standard Chinese and French

The questionnaire contained a series of questions aiming to determine which languages were associated with the respondents' cultural habits. For these questions, we did not ask about the use of dialects, since, apart from Cantonese and Taiwan Hokkien, other Chinese dialects do not have any cultural visibility ${ }^{15}$. Question 12 referred to popular culture, Question 13 to reading habits and Question 14 to writing habits, including personal letters and e-mails ${ }^{16}$.

Answers to questions bearing on cultural, reading and writing habits once again display a difference between respondents born in France, for whom French is clearly dominant, and respondents born in China, for whom Putonghua is still very much used. This is shown in Tables $6 \mathrm{a}$ and $6 \mathrm{~b}$ below.

\footnotetext{
15 Taiwanese are not among the Chinese-speaking migrants who traditionally chose France to settle; as for Cantonese-speaking migrants, they could be part of the second or third migrating waves from Indochina (see part 1), or be recent migrants. There were as many as eight youths among our respondents who claimed Cantonese as a first or second language. All of them were born in France. Since we did not expect them to be so numerous, we didn't ask about Cantonese-speaking media.

${ }^{16}$ As was the case in Table 5, total number of answers may not always amount to 88 , since some of the younger children did not answer all the questions.
} 
Table 6a.

Cultural habits and language use for respondents born in France

\begin{tabular}{|l|l|c|c|c|}
\hline \multicolumn{2}{|c|}{} & French only & PTH only & French+PTH \\
\hline \multirow{4}{*}{ Popular culture } & Pop music & 25 & 4 & 9 \\
\cline { 2 - 5 } & TV & 34 & 2 & 8 \\
\cline { 2 - 5 } & DVDs & 27 & 12 & 3 \\
\hline \multirow{5}{*}{ Reading habits } & Newspapers & 31 & - & 6 \\
\cline { 2 - 5 } & Magazines & 44 & - & - \\
\cline { 2 - 5 } & Novels & 38 & - & 2 \\
\cline { 2 - 5 } & Internet & 29 & - & 5 \\
\hline \multirow{5}{*}{ Writing habits } & Letters & 33 & 1 & 2 \\
\cline { 2 - 5 } & E-mail & 33 & - & 2 \\
\cline { 2 - 5 } & SMS & 32 & - & 4 \\
\cline { 2 - 5 } & Online chat & 38 & - & 2 \\
\hline
\end{tabular}

Let us first comment our results as concerns youths and children born in France. The overall tendency is taht to use French as the main or only language for these occupations, with the exception of popular culture media that do not involve reading. As for those, the difference between TV programs and DVDs may be accountable in terms of availability: there are not that many Chinese language TV channels available in France (they're all available through the cable, at additional cost as compared to standard French-language channels), whereas pirate DVDs dubbed in Chinese are sold in many Chinese outlets in Paris. Nevertheless, more than half of the respondents reported they watched DVDs in French only (27/44), and 3 more reported that part of the DVDs they watched were in French.

As or reading habits, they are also dominated by French. Table 6a shows that Putonghua may play a role for newspaper reading (there are two daily newspapers in standard Chinese edited in Paris, plus a few other periodic publications, mainly free of charge). More importantly, standard Chinese is cited, in association with French, in connection with the Internet. But children and youths claiming to read in Chinese on the Internet (alone or in combination with French) still represent less than a third of the respondents.

Writing habits, as shown in Table 6a, were similarly dominated by French, although Putonghua was claimed to be used, mostly in combination with French, 
by a small part of the respondents. It is not surprising that more respondents claim to use standard Chinese when writing letters or e-mails than for instant messaging. Letters and e-mails are usually written for people who live far away, as could be the case for relatives and friends in China.

Let us now turn to the responses given by children and youths who were born in China as displayed in Table 6b.

Table $6 b$.

Cultural habits and language use for respondents born in China

\begin{tabular}{|l|l|c|c|c|}
\hline \multicolumn{2}{|c|}{} & French only & PTH only & French+PTH \\
\hline \multirow{4}{*}{ Popular culture } & Pop music & 4 & 27 & 12 \\
\cline { 2 - 5 } & TV & 12 & 16 & 16 \\
\cline { 2 - 5 } & DVDs & 5 & 28 & 9 \\
\hline \multirow{5}{*}{ Reading habits } & Newspapers & 7 & 21 & 9 \\
\cline { 2 - 5 } & Magazines & 19 & 14 & 8 \\
\cline { 2 - 5 } & Novels & 17 & 20 & 7 \\
\cline { 2 - 5 } & Internet & 8 & 21 & 15 \\
\hline \multirow{5}{*}{ Writing habits } & Letters & 9 & 23 & 7 \\
\cline { 2 - 5 } & E-mail & 5 & 30 & 7 \\
\cline { 2 - 5 } & SMS & 15 & 15 & 8 \\
\cline { 2 - 5 } & Online chat & 2 & 31 & 71 \\
\hline
\end{tabular}

As can be seen when comparing the two preceding tables, the use of Putonghua is far more frequent for respondents born in China in the three domains related to cultural habits. However, we can see that these respondents also use French, especially as related to local media (television, magazines). The high score of novels in French may be related to the fact that respondents mainly read novels when assigned to do so at school. As for writing habits, the medium for which French was the most reported (and standard Chinese the less reported) was instant messaging via mobile phone, which can be explained by the fact that mobile phones used in France at the time of the survey seldom allowed the use of Chinese script. But such a restriction does not hold for computer-based communication (e-mail and chat). Letters and e-mails, presumably addressed in part to relatives and friends in China, do not use French to the same extent as Putonghua. 
If we sum up our findings so far, the questionnaire showed that most respondents listed Putonghua as one of the languages in their linguistic repertoire, even when they were born and raised in France. As for reported language use however, there was a clear divide between respondents who were born in France and those who were born in China. Most of the former cited French as their most used language, except when communicating with their parents. On the contrary, most of the latter cited Putonghua as their most used language, but other languages such as Chinese dialects or French also played a role in their linguistic repertoire. They also tended to use more dialect in intra-familial communication (especially with their parents) than their French-born counterparts. Their use of French seems to be linked to the dominant cultural habits in their new place of residence.

If we take a closer look at Putonghua, we may see two distinct tendencies: (1) as opposed to Chinese dialects, Putonghua is gaining ground, since it is now part of the family languages, whereas dialects seemed dominant in this setting ten years before; and (2) as opposed to French, Putonghua is often learned voluntarily when learned in France, but is seldom used in peer-to-peer communication or for writing and reading purposes.

The next two questions were aimed at elicitating respondents' attitudes towards the three languages.

\section{Attitudes towards languages}

Questions 16 ("Which languages would you like your own children to speak?") and 17 ("Which languages would you like to transmit personally to your own children?") were indirect questions about language attitudes: which languages are worth knowing, which languages are worth transmitting to the next generations.

It is not very easy to draw conclusions from the answers we obtained to these two questions. Very often, respondents cited fewer languages for Question 16 than for Question 17, or different languages altogether. Moreover, these questions being aimed at elicitating attitudes rather than language uses, we should take them for no more than what they really are: appreciation as to the social (Question 16) or emotional (Question 17) value of languages. Thus, in the 
following figures, we count the number of times a given language was cited, rather than the language combinations. Moreover, we disregard languages like English, Spanish, German or Italian, mentioned by some of the respondents in answer to Question 16, because they do not entertain the same relationship with Chinese languages as French does in the survey setting.

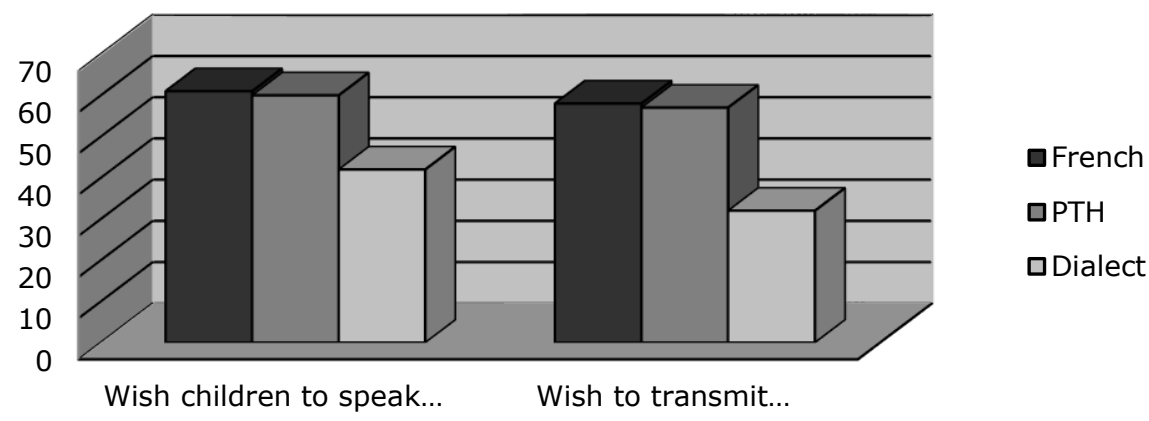

Fig. 1. Total number of citations per language (Questions 16 and 17)

From the number of citations per language as shown in Figure 1, we can see that the value conferred to all three languages, French, Putonghua and Chinese dialect, is quite close. Nevertheless, there is a decline between the three, and their ordering is the same for both questions, with French being more often cited than Putonghua, and Putonghua more often cited than Chinese dialect. However, since language uses differ for both categories of respondents, we may find that language attitudes also differ. In Figures $2 a$ and $2 b$, the preceding results are split according to whether respondents were born in France or in China.

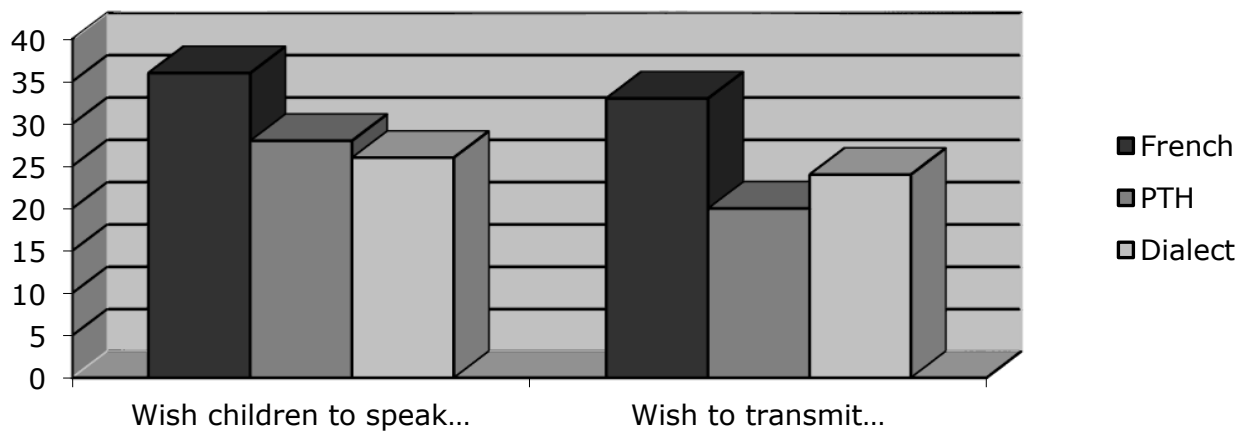

Fig. 2a. Total number of citations per language for respondents born in France 
For respondents born in France, the general ordering of the three languages is the same as the general ordering shown in Figure 1 as to wishing what languages their children could speak (instrumental value). This seems quite an accurate estimate of the value of the French language in the French setting. The position of standard Chinese in this rating may show that the respondents keep professional and geographical mobility in mind, whereas the rating of Chinese dialect points to the value of their personal history and identity. However, when it comes to emotional value, the dialect is rated higher than the standard Chinese language. Respondents trust they would be able to transmit it to the next generation.

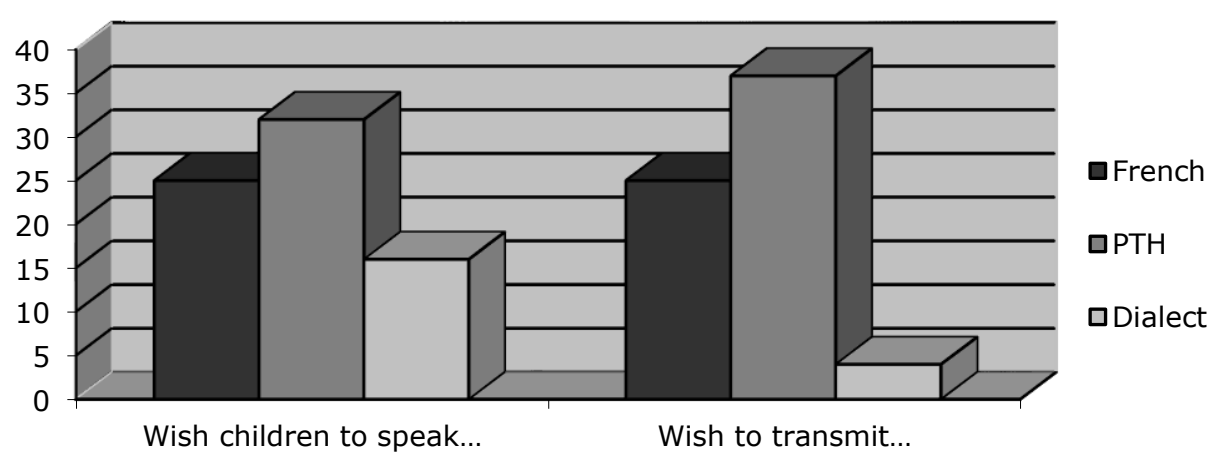

Fig. $2 b$. Total number of citations per language for respondents born in China

The pattern displayed in Figure $2 b$ is obviously different both from the general results (Figure 1) and for results displayed in Figure 2a. For respondents born in China, Putonghua comes first both as to social and emotional value. French comes only second. As to the Chinese dialects, although a significant part of the respondents wish their children could speak them, much less think they would take the pains to teach them to the next generation. It seems that, when respondents born in China answered Question 17, they bestowed the value denied to dialects on Putonghua instead. 


\section{Discussion}

We started this chapter by asking whether the changing status of Putonghua in China and globally had any impact on its use among Chinese migrants in France. The small-scale survey we launched in 2010 was not devised to explore the causes of the evolution that is taking place among Chinese migrant youths and children as to their language uses. It was primarily devised to make sure there were real changes, and which they were.

After comparing the results of our 2010 survey and the findings of the 2000 Saillard and Boutet survey, ${ }^{17}$ we claim that language use patterns among Chinese migrants to France are indeed changing, although the respondents and the data collection methods of the two surveys were not exactly the same. In particular, the 2010 survey was able to compare two kinds of children and youths from Chinese descent: half of them were born in China, and half of them in France, and find that they indeed reported different behaviors.

Our avowedly small-scale study addressed issues about three distinct languages or language types: French as the national language, standard Chinese (Putonghua) as a language related to cultural identity, and Chinese dialects as languages of family and territorial identity.

Our results tend to support the view that standard Chinese is indeed gaining popularity among migrants in settings where dialects were formerly dominant, such as the family and friends circle. This finding is arguably similar to what Liu and Wiley (2011) report regarding Chinese immigrants and international students in the United States. In their questionnaire survey, when respondents from Mainland China were asked which language they used with family and close relatives, the answer "mostly standard Chinese" was slightly more frequent than "mostly dialect", both being much more frequent than "dialect and standard Chinese fairly equally". In all other settings other than "the hometown" (in China), standard Chinese was clearly dominant for communication with other ethnic Chinese. Similarly, Wang (2011) documents "the spread of standard Chinese in the Home Domain" in Malaysia through questionnaires, interviews and observation, with a clear shift from the grandparents' generation, using mainly dialect, to the parents, using both dialect and standard Chinese, and finally to the

17 Saillard and Boutet (2001). 
children, using mainly standard Chinese. Although we didn't ask about communication with grandparents in our study, assuming most grandparents were still living in China and communication with grandchildren was scarce, our results, especially when compared to the 2000 Saillard and Boutet survey, arguably exhibit a language shift pattern. In parent-children communication, the Chinese dialects are seen to make way to way to standard Chinese, and in a lesser measure, to the French language. It still remains to be investigated whether the introduction of standard Chinese in the family domain originated with a shift in the parents' own language use patterns, by some collective social awareness of the importance of Chinese as a global language, or because of the continued and increasing arrivals of young people who received (part of) their education in China. As to French, it clearly entered the home domain through the children's generation, where it is often reported as used between respondents who were born in France and their siblings. The use of French in the family domain thus seems to be spreading from the children to the parents' generation.

Thus, it appears that both standard Chinese and French compete as languages to be used in the family and friends' circles. Our results show however that both languages do not have the same patterns of use. Even though standard Chinese is now acquired in France by children born away from China, its use seems restricted to communication involving Chinese adults, or Chinese youths born and educated in China.

Last, we would like discuss answers related to the use and transmission of Chinese dialects. One of the surprising facts uncovered by our survey was that even for youths born in so-called dialectal areas (Wenzhou, Fuqing, Qingtian...), the most often reported first language was Putonghua, not Wenzhouhua. Similarly for these respondents, Putonghua was the language conferred the most social and emotional value. Although Chinese dialects seem to be still used in the family and friends circle, they tend to be used mostly in connection with parents (and presumably grandparents, as is the case in Malaysia, see Wang (2011)). This is not enough to ensure that they will effectively be transmitted to the next generations, even though today's young people may wish so. 


\section{Some implications for heritage language teaching}

As is the case for other international languages, such as Arabic, the teaching of Chinese as a heritage language is confronted by a major question: which "Chinese" is to be taught? But, unlike colloquial Arabic, Chinese dialects have no "national standards", nor do they usually have a written corpus, be it literary or other ${ }^{18}$. Thus, the teaching of "Chinese" univocally refers to the standard Chinese language, Putonghua.

In that respect, teachers will find that they cannot rely as much as would be expected on the preexisting language skills of their pupils. Proficiency in a Chinese dialect as acquired at home may be a source of positive as well as negative transfer, be it at the phonetic, lexical or syntactic level.

One of the well-known difficulties of the Chinese language has to do with its non-alphabetic script. Because the acquisition of this script is very time- and effort-consuming, because it is better learnt when presented with its own logic (disconnected from the actual frequency of the corresponding oral terms), teaching the Chinese language using a truly communicative approach remains a real challenge. Teachers will have to devote part of their time teaching the Chinese script apart from the spoken language, if any efficiency in reading and writing skills is aimed at.

This is the reason why, as shown by our study, children and youths that have received even only part of their schooling in China are at an advantage for using the language in its written forms (see Tables $6 \mathrm{a}$ and $6 \mathrm{~b}$ above). Schooling in China devotes a huge amount of time to developing reading and writing skills. Teaching Chinese as a heritage language, often only for two or three hours a week, is not going to bridge the gap between pupils learning to read and write Chinese in China and pupils learning the language abroad. While pupils can be encouraged to speak Putonghua with members of their family or community, access to written materials is much more difficult for them. Thus, teachers should devote part of their lessons to help the pupils achieve communicative tasks that require reading or writing, using facilitating tools such as computers ${ }^{19}$.

\footnotetext{
${ }^{18}$ Except for Cantonese, written in Hong Kong.

19 Various key-in systems developed for the Chinese script render writing much easier through electronic devices than it is by hand.
} 


\section{Conclusion}

Although our study shows that the official language of China, Putonghua, is indeed developing among young migrants from Chinese origin in Paris, it is also apparent that only the more skilled children (those that have received schooling in China) effectively use Putonghua in all social arenas. Thus, children and youths from Chinese background will have to find more ways to use Putonghua in their daily lives in order to strengthen their skills. Standard Chinese is available in France through popular culture (mainly the Internet, but also DVDs, television, pop music...), but it has yet to equal the use of French. The latter was shown by our questionnaires to be clearly dominant in peer-to-peer communication for children born in France, and to have a high symbolic value.

As to the Chinese dialects, they seem to be losing ground in their traditional sphere of use: the family and friends domains. This is due to the development of both Putonghua and French in the linguistic repertoires of migrant youths and children. For reasons outlined in the preceding section, Chinese dialects cannot benefit from the presence of informal Chinese language schools in Paris. Although our respondents (especially those born in France) seem to confer emotional value to their family dialect, it is to be feared that transmission to the next generation will not be the rule. I so, it is potentially the standard language, Putonghua, that will be the hallmark of Chinese ethnicity among migrants in France, as in other parts of the world.

\section{References}

Boutet, J., \& Saillard, C. (2003). Dynamique des répertoires linguistiques dans la migration chinoise. In J. Billiez (Ed.), Contacts de Langues. Modèles, typologies, interventions (pp. 91-109). Paris: L'Harmattan.

Boutet, J., \& Saillard, C. (2013). Les langues chinoises en France: L'exemple de la migration wenzhou. In Histoire sociale des langues de France (pp. 891899). Paris: Collectif HSLF.

Cattelain, C., Lieber, M., Moussaoui, A., Ngugen, S., Poisson, V., Saillard, C., \& Ta, C. (2002). Les modalités d'entrée des ressortissants chinois en France. Paris: Direction des Populations et des Migrations. 
Cattelain, C., Lieber, M., Saillard, C., \& Ngugen, S. (2005). Les déclassés du Nord. Une nouvelle migration chinoise en France. Revue Européenne Des Migrations Internationales, 21(3), 27-52.

Ferguson, C. A. (1959). Diglossia. Word -Journal of the International Linguistic Association, 15(2), 325-340.

French ministry of Education (2015). Repères et références statistiques sur les enseignements, la formation et la recherche, 2015, French Ministry of Education, August 2015. Retrieved from http://www.education.gouv.fr/ cid57096/reperes-et-references-statistiques.html.

Héran, F., Filhon, A., \& Deprez, C. (2002). La dynamique des langues en France au fil du XXe siècle. na.

Liu, N., \& Wiley, T. (2011). Attitudes toward standard Chinese, dialects, and language diversity among Chinese immigrants and international students in the United States. Presented at the The International Symposium on China's 100 years of Language Planning, University of Maryland.

Ma Mung, E. (2009). Le prolétaire, le commerçant et la diaspora. Revue Européenne Des Migrations Internationales, 25(1), 97-118.

Mair, V. H. (1991). What is a Chinese "dialect/topolect"?: Reflections on Some Key Sino-English Linguistic Terms. Sino-Platonic Papers, 29. Retrieved from http://sino-platonic.org/complete/spp029_chinese_dialect.html.

Pina-Guérassimoff, C. (2006). Le renouvellement des perspectives transnationales de la Chine. Critique Internationale, 32, 39-52.

Saillard, C. (2004). On the promotion of Putonghua in China: How a standard language becomes a vernacular. In M. Zhou (Ed.), Language policy in the People's Republic of China: Theory and practice since 1949 (pp. 163-176). Dordrecht: Kluwer.

Saillard, C., \& Boutet, J. (2001). Pratiques des langues chez les jeunes issus de l'immigration chinoise à Paris. Paris: Délégation Générale à la Langue Française.

Saillard, C., \& Boutet, J. (2008). Construction des répertoires langagiers dans la migration Wenzhou (Chine) à Paris. Cahiers de I'Observatoire Des Pratiques Linguistiques, 2, 72-76.

Trolliet, P. (1994). La diaspora chinoise. Paris: Presses Universitaires de France. 
Wang, X. (2011). Can a language spread from bottom upwards? A study on the spread of Standard Chinese in Johor, Malaysia. Presented at the The International Symposium on China's 100 years of Language Planning, University of Maryland.

Appendix 1

\section{Questionnaire}

Identification of respondent: ... Place: ...

1. How old are you?

2. Where were you born? $\square$ In China (City: ) $\square$ In France $\square$ Other:

3. Did you go to school in China? $\square$ Yes $\square$ No

If yes, up to which grade? ...

4. How long have you been staying in France: ...

5. What is you mother tongue? $\square$ French $\square$ Putonghua $\square$ other: ...

6 . Can you speak another language? $\square$ Putonghua $\square$ Chinese dialect: .... $\square$ other:

7. Where and how did you learn

- Putonghua:

- Chinese dialect:

- French:

- other:

8. Which languages do you speak at home? More precisely:

- your parents speak to you: $\square$ dialect $\square$ Putonghua $\square$ French

- you speak to your parents: $\square$ dialect $\square$ Putonghua $\square$ French

- you speak to your elder siblings: $\square$ dialect $\square$ Putonghua $\square$ French

- you speak to your younger siblings: $\square$ dialect $\square$ Putonghua $\square$ French

9. Which languages do you speak to your Chinese classmates:

- from the same area as yours: $\square$ dialect $\square$ Putonghua $\square$ French

- from other areas: $\square$ dialect $\square$ Putonghua $\square$ French

10. What is the mother tongue of your two best friends?

11. Your voicemail message is recorded in $\square$ dialect $\square$ Putonghua $\square$ French

12. In which language do you watch or listen to:

- pop music: $\square$ Putonghua $\square$ French

- TV: $\square$ Putonghua $\square$ French

- DVDs: $\square$ Putonghua $\square$ French

13. In which language do you read:

- newspapers: $\square$ Putonghua $\square$ French

- magazines: $\square$ Putonghua $\square$ French

- novels: $\square$ Putonghua $\square$ French

- Internet pages: $\square$ Putonghua $\square$ French

14. In which language do you write:

- personal letters: $\square$ Putonghua $\square$ French

- e-mails: $\square$ Putonghua $\square$ French

- SMS: $\square$ Putonghua $\square$ French

- chat or instant messaging on the Internet: $\square$ Putonghua $\square$ French

15. Which language do you speak with your Chinese friends when you are in a public place (on the street, the metro, in the schoolyard, on a sports field...)? dialect $\square$ Putonghua $\square$ French 
16. Which language would you wish your own children to speak?

$\square$ dialect $\square$ Putonghua $\square$ French $\square$ other: ...

17. Which language would you wish to transmit yourself to your children?

$\square$ dialect $\square$ Putonghua $\square$ French $\square$ other: ...

Appendix 2.

Ages of respondents

\begin{tabular}{|c|c|c|c|c|c|c|c|}
\hline Age & $\mathbf{7}$ & $\mathbf{8}$ & $\mathbf{9}$ & $\mathbf{1 0}$ & $\mathbf{1 1}$ & $\mathbf{1 2}$ & $\mathbf{1 3}$ \\
\hline $\begin{array}{c}\text { Nb of } \\
\text { respondents }\end{array}$ & 5 & 6 & 8 & 6 & 6 & 10 & 13 \\
\hline Age & 14 & 15 & 16 & 17 & 18 & 19 & \\
\hline $\begin{array}{c}\text { Nb or } \\
\text { respondents }\end{array}$ & 5 & 8 & 9 & 7 & 3 & 2 & \\
\cline { 1 - 5 } & & & &
\end{tabular}

\section{Claire Saillard}

Paryžiaus Diderot universitetas, Prancūzija; claire.saillard@linguist.univ-paris-diderot.fr

\section{KINTANTYS REPERTUARAI: MIGRACIJA IR KINU KALBOS PRANCŪZIJOJE}

Santrauka. Šiame straipsnyje pristatomas tyrimas rodo, kad kinu migrantu i Paryžiu, Prancūzija, kalbu repertuarai per pastaruosius 15 metu pakito tiek dèl sociologiniu, tiek dèl sociolingvistiniu pokyčiu, atsiradusiu nuo 2000 metu pradžios. Sociologiniu požiūriu, dar tebesitęsianti migracija iš Kinijos i Prancūziją vyksta tuo pačiu metu, kai formuojasi jau Prancūzijoje migrantu šeimose gimusiu etniniu kinu vaiku ir jaunuoliu karta. Sociolingvistiniu požiūriu, akivaizdu, kad pusiausvyra tarp standartinès kinu nacionalinès kalbos (Putonghua) ir vietinès kinu kalbos (fangyan ar "dialektu”) jau nebèra diglosinè situacija, kai standartinè kalba nevartojama šeimoje ar bendraujant su draugais. Abieju rūšiu pokyčiu pasekmės tirtos taikant nedidelès apimties anketinę apklausa, kurioje dalyvavo Paryžiuje gyvenantys etniniai kinu vaikai ir jaunuoliai. Gauti duomenys buvo palyginti su panašiais duomenimis, gautais 2000 metais. Rezultatai rodo ivykusi dideli pasikeitima kinu migrantu i Prancūzija lingvistiniame repertuare. Tyrimo pabaigoje apžvelgiamos kai kurios tyrimu rezultatu implikacijos paveldètosios kalbos mokymui.

Pagrindinès sąvokos: kalbu repertuaras, kalbos vartojimas, požiūriai i kalbą, kinai, migracija, anketinè apklausa. 